\title{
Building age, type of indoor heating and the occurrence of allergic rhinitis and asthma
}

\author{
Barbara Piekarska1, Konrad Furmańczyk ${ }^{1,2}$, Stanisław Jaworski ${ }^{1,3}$, Bożenna Stankiewicz-Choroszucha ${ }^{1}$, \\ Edyta Krzych-Fałta ${ }^{1}$, Artur Z. Białoszewski ${ }^{1}$, Anna Kłak ${ }^{1}$, Bolesław K. Samoliński ${ }^{1}$
}

1Department of Prevention of Environmental Hazards and Allergology, Medical University of Warsaw, Warsaw, Poland ${ }^{2}$ Department of Applied Mathematics, Faculty of Applied Informatics and Mathematics, Warsaw University of Life Sciences, Warsaw, Poland

${ }^{3}$ Department of Econometrics and Statistics, Faculty of Applied Informatics and Mathematics, Warsaw University of Life Sciences, Warsaw, Poland

Adv Dermatol Allergol 2020; XXXVII (1): 81-85 DOI: https://doi.org/10.5114/ada.2019.85288

\begin{abstract}
Introduction: Structural materials and interior appliances are frequently mentioned as elements of modern buildings which may have an impact on the natural history of allergic diseases.

Aim: We hypothesized that the building age, the type of the heating system and the use of various indoor appliances can influence the occurrence of allergic rhinitis (AR) and asthma.

Material and methods: The study group comprised 18,617 individuals. The tool used in the study was the European Community Respiratory Health Survey (ECRHS) and the International Study of Asthma and Allergies in Childhood (ISAAC) study questionnaire, adapted to European conditions (Middle and Eastern Europe) and used as part of the study called "Implementation of a System for the Prevention and Early Detection of Allergic Diseases in Poland". Results: Questionnaire results indicated that people living in homes built in the years 1971-1990 had higher rates of allergic rhinitis $(O R=1.15025)$, which was correlated with clinical findings of increased occurrence of seasonal allergic rhinitis $(O R=1.60543)$. The leading factor contributing to the intensification of AR symptoms was the central heating $(O R=1.45358)$. As opposed to $A R$, people living in buildings with central heating less often declared asthma $(O R=0.8407)$. A clinical examination confirmed that central heating reduced the symptoms of moderate asthma $(O R=0.3524)$.

Conclusions: Increasing building age and certain indoor heating methods are important risk factors for the occurrence of allergic rhinitis and asthma.
\end{abstract}

Key words: age of the building, indoor environmental factors, allergic rhinitis, asthma, indoor heating.

\section{Introduction}

The impact of indoor conditions on health has been a subject of interest for researchers from various disciplines for many years. Air quality, lighting, indoor temperature, noise, humidity, mould, presence of heavy metals, neglect of hygiene and overcrowding are just some of the factors that generate residents' health problems. Modern living conditions have far-reaching implications related to lifestyle or dietary habits as well as our work/ home microenvironments. Studies have shown that up to $30 \%$ of people report general malaise, constant fatigue, headaches, dizziness, irritation of the eyes and skin, and difficulty breathing, a constellation of symptoms termed "sick building syndrome" [1-5]. Adults living in developed countries, especially those inhabiting urban areas, now spend, on average, over $80 \%$ of their time indoors [4-9]. Other studies place this figure as high as 60-90\% [10]. This percentage may be even higher among children as well as elderly and sick people, making these groups theoretically most severely exposed to indoor airborne factors harmful to health [7].

Indoor air quality is a term referring to air quality inside buildings as it relates to various parameters such as temperature, humidity, ventilation and the presence of indoor chemical or biological contaminants. Clean air in the home is very important for the health of the popu-

Address for correspondence: Artur Z. Białoszewski MA, Department of Prevention of Environmental Hazards and Allergology, Medical University of Warsaw, 61 Żwirki i Wigury St, 02-091 Warsaw, Poland, phone: +48 501 131 823/+48 225 992 039, e-mail: artur.bialoszewski@wum.edu.pl, artur.bialoszewski@gmail.com Received: 22.06.2018, accepted: 15.10.2018. 
lation as a whole and especially for vulnerable populations, such as infants, children, the elderly or individuals already suffering from respiratory or allergic conditions. Many factors related to indoor living may have an impact on allergic diseases and those most frequently mentioned in the literature include:

- ambient temperature, humidity, and impurities from the outdoor environment;

- regional climate;

- construction materials and maintenance of the building;

- air conditioning type;

- interior appliances [6].

\section{Aim}

Determine the effects of building age, heating system type and use of various indoor appliances on the occurrence of allergic rhinitis (AR) and asthma.

\section{Material and methods}

The aim of this study was to determine the effects of building age, heating system type and use of various indoor appliances on the occurrence of AR and bronchial asthma (BA) among the participants of the Epidemiology of Allergic Diseases in Poland (ECAP) project. ECAP used the methodology of the International Study of Asthma and Allergies in Childhood (ISAAC) and the European Community Respiratory Health Survey (ECRHS). The study areas were selected according to the ECRHS guidelines.

ECAP involved the populations of the eight largest urban agglomerations in Poland and additionally one rural region, also with a population of over 150000 inhabitants since the rural population accounts for $39 \%$ of the entire Polish population. The study group was selected randomly from the Polish Resident ID Number (PESEL) registry at the Ministry of the Interior and Administration.

The research tool used in the study was the European Community Respiratory Health Survey (ECRHS) and International Study of Asthma and Allergies in Childhood (ISAAC) study questionnaire, adapted to European conditions (Middle and Eastern Europe) and used as part of the implementation of the System for the Prevention and Early Detection of Allergic Diseases in Poland study. It was a two-stage study, with the first stage involving subject enrolment (22,703 respondents) based on the questionnaire with the help of a PDA (Personal Digital Assistant). This survey-based study used translated and validated ECRHS and ISAAC questionnaires as well as a physical examination conducted according to ECRHS Il standards.

The second stage involved 4,873 outpatient respondents who underwent additional diagnostic tests: skinprick tests, lung function test, and peak nasal inspiratory flow (PNIF) evaluation. Clinical diagnoses of AR (includ- ing perennial $A R$ and seasonal $A R$ ) and $B A$ were verified based on the Allergic Rhinitis and its Impact for Asthma (ARIA) and Global Initiative for Asthma (GINA) guidelines. Only data from cities were analysed due to the dissimilar nature of urban and rural housing and their indoor furnishings (heaters, appliances, etc.). The questionnaire consisted of questions concerning health, respiratory diseases and symptoms of allergic diseases and asthma.

\section{Statistical analysis}

Differences in the prevalence of allergic diseases and asthma depending on the age of the building, the indoor heating method used in the building, and furnishings were expressed using odds ratios (OR) for contingency tables with a $95 \%$ confidence interval $(95 \% \mathrm{Cl})$. Statistical analysis was performed using the contingency tables and the $\chi^{2}$ test of independence. Statistical differences (dependence) were considered as significant at $p<0.05$ for the $\chi^{2}$ test. The following age categories were established for analysis of current housing age: 1900-1945, 1946-1970, 1971-1990, and > 1990. Months were also grouped into seasons (spring, summer, autumn and winter) for analysis of temporal trends in the presence of symptoms associated with allergic rhinitis.

\section{Results}

The questionnaire data revealed that the negative impact of indoor air quality on the presence of allergic rhinitis occurred most frequently in homes built in the years 1971-1990. People living in these buildings often reported allergic rhinitis (Table 1 ).

Use of central heating may also influence the effect of these factors and intensify symptoms of seasonal allergic rhinitis of apartment residents living in buildings constructed after 1990. This finding correlated with clinical examination results (Table 2).

As opposed to AR, people living in buildings with central heating less often reported the occurrence of asthma (Table 3). A clinical examination confirmed that central heating reduced the symptoms of moderate asthma (Table 4).

Statistical analysis relating to the presence of heating appliances fired by solid fuel confirmed their impact on problems with breathing (such as wheezing, tightness in the chest or shortness of breath) (Table 5).

Medical examination of respondents who used solid fuel (coal, coke or wood) for water heating or in an open furnace showed increased presence of moderate asthma (OR $=2.90080,95 \% \mathrm{Cl}: 1.69773-4.95641, p=$ $0.0000457)$ and severe asthma $(O R=2.20592,95 \% \mathrm{Cl}$ : $1.255283-3.876510, p=0.004797)$. This also applies to residents of homes equipped with gas stoves, used for home water heating. They more often reported wheezing and breathing difficulty $(O R=1.219709,95 \% \mathrm{Cl}$ : 1.098635-1.3541267, $p=0.000193)$. 
Table 1. The occurrence of AR versus year of construction of the house currently inhabited and the presence of central heating

\begin{tabular}{|c|c|c|c|c|c|c|c|}
\hline \multirow[t]{2}{*}{ Factor } & & \multicolumn{2}{|c|}{ Self-reported allergic rhinitis } & \multirow{2}{*}{$\begin{array}{l}\text { Odds ratio } \\
\left(\mathrm{OR}^{*}\right)\end{array}$} & \multirow{2}{*}{\multicolumn{2}{|c|}{$\begin{array}{l}\text { 95\% confidence interval }(\mathrm{Cl}) \\
\text { for OR }\end{array}$}} & \multirow{2}{*}{$\begin{array}{l}P \text {-value } \\
\text { of } \chi^{2} \text { test }\end{array}$} \\
\hline & & No & Yes & & & & \\
\hline \multicolumn{8}{|c|}{ Year of construction of building (age of building): } \\
\hline 1900-1945 & & 1243 & 334 & & & & \\
\hline $1946-1970$ & & 3298 & 955 & 1.0776 & 0.9362 & 1.2403 & 0.2972 \\
\hline 1971-1990 & & 4769 & 1474 & 1.1502 & 1.005 & 1.3154 & 0.0407 \\
\hline$>1990$ & & 2708 & 818 & 1.1241 & 0.9735 & 1.2981 & 0.1108 \\
\hline \multirow[t]{2}{*}{ Central heating } & No & 1711 & 449 & & & & \\
\hline & Yes & 12657 & 3743 & 1.1253 & 1.0079 & 1.2563 & 0.0355 \\
\hline
\end{tabular}

${ }^{*}$ ORs for year of construction were calculated against data for 1900-1945.

Table 2. The occurrence of SAR versus year of construction of the house currently inhabited and the presence of central heating

\begin{tabular}{|c|c|c|c|c|c|c|c|}
\hline \multirow[t]{2}{*}{ Factor } & & \multicolumn{2}{|c|}{$\begin{array}{c}\text { Recognized seasonal allergic } \\
\text { rhinitis nasal }\end{array}$} & \multirow[t]{2}{*}{$\begin{array}{l}\text { The odds ratio } \\
\text { (OR) }\end{array}$} & \multirow{2}{*}{\multicolumn{2}{|c|}{$95 \%$ confidence interval $(\mathrm{Cl})$}} & \multirow[t]{2}{*}{$P$-value } \\
\hline & & No & Yes & & & & \\
\hline \multicolumn{8}{|c|}{ Year of construction of a building (age of building): } \\
\hline $1900-1945$ & & 237 & 30 & & & & \\
\hline $1946-1970$ & & 389 & 72 & 1.46221 & 0.9272 & 2.3058 & 0.1006 \\
\hline 1971-1990 & & 676 & 133 & 1.55428 & 1.0183 & 2.3723 & 0.0397 \\
\hline$>1990$ & & 497 & 101 & 1.60543 & 1.0382 & 2.4826 & 0.0321 \\
\hline \multirow{2}{*}{$\begin{array}{l}\text { Central heating in the } \\
\text { building }\end{array}$} & No & 268 & 35 & & & & \\
\hline & Yes & 1,928 & 366 & 1.45358 & 1.0044 & 2.1034 & 0.0461 \\
\hline
\end{tabular}

*ORs for year of construction were calculated against data for 1900-1945.

Table 3. Self-reported asthma in relation to the presence of central heating. Odds ratio for self-reported asthma with regard to the presence of central heating

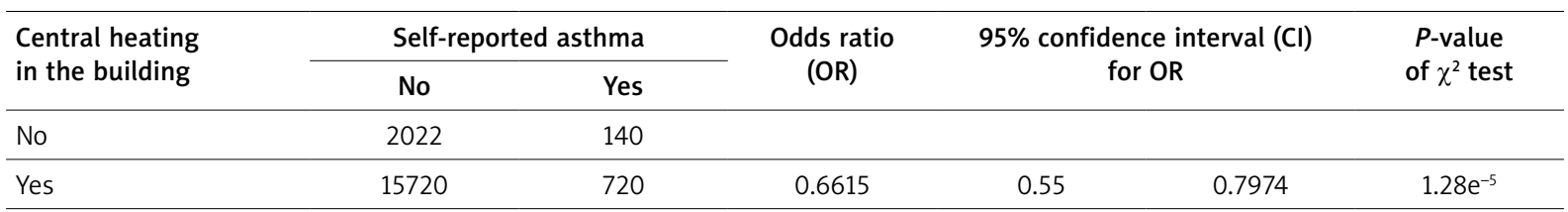

Table 4. Correlation between diagnosed moderate asthma and the presence of central heating in the building

\begin{tabular}{lcccccc}
\hline $\begin{array}{l}\text { Central heating } \\
\text { in the building }\end{array}$ & \multicolumn{3}{c}{ Moderate asthma diagnosed } & \multirow{2}{*}{$\begin{array}{c}\text { The odds ratio } \\
\text { (OR) }\end{array}$} & $\begin{array}{c}95 \% \text { confidence interval (Cl) } \\
\text { for OR }\end{array}$ & $\begin{array}{c}P \text {-value } \\
\text { of } \chi^{2} \text { test }\end{array}$ \\
\cline { 2 - 3 } & No & Yes & & & & \\
\hline No & 487 & 17 & & & & \\
\hline Yes & 4227 & 52 & 0.3524 & 0.2021 & 0.6142 & 0.0001 \\
\hline
\end{tabular}

\section{Discussion}

Other gas appliances or solid fuel equipment used for home water heating had no significant effect on the occurrence of respiratory symptoms in the respondents.
The results from our institution as well as research centres around the world, including China, Great Britain, Canada and Sweden, confirm the complex nature of the relationship between indoor environmental factors and 
B. Piekarska, K. Furmańczyk, S. Jaworski, B. Stankiewicz-Choroszucha, E. Krzych-Fałta, A.Z. Białoszewski, A. Kłak, B.K. Samoliński

Table 5. Problems with breathing (such as wheezing, tightness in the chest and shortness of breath) in relation to the type of the home/water heating system using an open coal, coke or wood-fired furnace

\begin{tabular}{|c|c|c|c|c|c|}
\hline \multirow[t]{2}{*}{$\begin{array}{l}\text { Coal-, coke- or wood- } \\
\text { fired furnace for } \\
\text { heating home (water) }\end{array}$} & \multicolumn{2}{|c|}{$\begin{array}{l}\text { Problems with breathing } \\
\text { (such as wheezing, tightness in the } \\
\text { chest and shortness of breath) }\end{array}$} & \multirow[t]{2}{*}{$\begin{array}{l}\text { The odds ratio } \\
\text { (OR) }\end{array}$} & \multirow[t]{2}{*}{$95 \% \mathrm{Cl}$ for OR } & \multirow[t]{2}{*}{$\begin{array}{l}P \text {-value } \\
\text { of } \chi^{2} \text { test }\end{array}$} \\
\hline & No & Yes & & & \\
\hline No & 1548 & 669 & & & \\
\hline Yes & 182 & 107 & 1.36037 & 1.05374 & 0.0178 \\
\hline
\end{tabular}

irritants and allergic diseases [2, 3, 8, 11]. Indoor air quality deserves special attention because it is present in the area where people spend the greater part of the day, and recent studies indicate that the concentration of toxic substances in indoor air often exceeds concentrations measured outdoors. ECAP results confirm that air quality is affected by building age, heating system type and indoor appliances used. Even though we did not perform measurements of concentrations of chemicals released from sources located in indoor areas, our results are consistent with the available literature [9, 11, 12].

In cities, the biggest influence of indoor factors was noted in buildings erected in the years 1946-1990. Construction materials used for residential buildings in Poland in these years evolved with technological capabilities and were dependent on the availability of specific raw materials.

Common building and finishing materials may contain harmful substances that may pose a risk to allergy sufferers, including formaldehyde and volatile organic compounds (VOCs) [2, 3, 5, 8, 9, 11-13].

A significant threat for people suffering from asthma is central heating, which itself is not an allergen, but, by reducing humidity, increases persistent cough, shortness of breath and tightness in the chest. Hot radiators and closed windows make the skin and mucous membranes very dry. Optimal humidity in the room is $45-55 \%$; in winter it is often reduced by half, sometimes even falling below $10 \%$. Many people start complaining about sneezing or a runny or blocked nose not caused by a cold or another infection.

Central heating may also cause exposure to other indoor allergens such as house dust mites [14-16]. Due to the accumulation of house dust mite allergens and reduced air ventilation in autumn and winter, seasonal allergic rhinitis reported by the participants of our study were more severe. Turning on the heating system increases air circulation and causes the house dust mite to rise along with the heated air. There are favourable conditions for exposure to the allergen accumulated during the summer [17].

There is conflicting evidence that suggests central heating systems both improve and aggravate asthma. This is obviously confusing, not to mention unsettling, especially for patients who want to ensure that they remain healthy. Data analysis showed an ameliorating effect of central heating on asthma. Central heating helps reduce humidity and maintain appropriate indoor temperature, which can be beneficial for people with asthma. Other heating technologies using solid fuels (wood, coal) and gas are not neutral for asthmatics [18].

Various heating technologies using solid fuels (wood, coal) and gas are shown to intensify symptoms of allergic diseases $[8,15,16]$.

Although indoor air concentrations of these contaminants were not measured quantitatively in the ECAP study, the data on the types of heating technologies used indicate the types of contaminants that may be present and their potential for indoor sequestration and/or release.

Emissions from coal combustion contain a large amount of pollutants, such as particulate matter, carbon monoxide, sulfur dioxide, nitrogen oxides and organic toxins. When wood is burned, the problem is more complex, because wood smoke includes a wider range of ingredients forming a complex mixture of particles of different chemical composition and physical characteristics. This makes it difficult to identify which components are particularly harmful. Research conducted by Thorn et al. showed an increased risk of asthma associated with the use of coal-fired furnaces [18]. Gas furnaces are considered the main source of $\mathrm{NO}_{2}$ in the rooms. Studies show that people using these devices are more likely to have wheezing, shortness of breath, asthma attacks and allergic rhinitis [3, 8, 19].

\section{Acknowledgments}

The authors wish to thank colleagues for their valuable help in editing. The authors specially thank you for your cooperation: Prof. Anna Bodzenta-Łukaszyk, Prof. Anna Bręborowicz, Marta Chełmińska MD, Daniel Paczesny PhD, Prof. Andrzej Emeryk, Prof. Andrzej Fal, Prof. Radosław Gawlik, Prof. Wiesław Gliński, Teresa Hoffman MD, Prof. Mirosław Jarosz, Prof. Ewa Jassem, Prof. Piotr Kuna, Prof. Jerzy Kruszewski, Prof. Teresa Kulik, Prof. Marek Kulus, Prof. Grzegorz Lis, Prof. Sławomir Majewski, Prof. Michał Musielak, Prof. Barbara Rogala, Prof. Wojciech Silny, Prof. Andrzej Szpak, Prof. Jan Zejda. 


\section{Conflict of interest}

The authors declare no conflict of interest.

\section{References}

1. Pałczyński C, Sick building syndrome. Alergia 2010; 2: 24-7.

2. Guo P, Yokoyama K, Piao F, et al. Sick building syndrome by indoor air pollution in Dalian, China. Int J Environm Res Public Health 2013; 10: 1489-504.

3. Chang CC, Ruhl RA, Halpern GM, et al. The sick building syndrome. I. Definition and epidemiological considerations. J Asthma 1993; 30: 285-95.

4. Pitarma R, Marques G, Ferreira BR. Monitoring indoor air quality for enhanced occupational health. J Med Syst 2017; 41: 23.

5. Saeki Y, Kadonosono K, Uchio E, Clinical and allergological analysis of ocular manifestations of sick building syndrome. Clin Ophthalmol 2017; 11: 517-22.

6. Bogacka E. The influence of dwellings on the allergic diseases prevalence and clinical signs. Alergia Astma Immunol 2011; 16: 75-9.

7. Pickett $A$, Bell M. Assessment of indoor air pollution in homes with infants. Int J Hyg Environm Health 2011; 8: 4502-20.

8. Kastner PE, Le Calvé S, Zheng W, et al. A dynamic system for single and repeated exposure of airway epithelial cells to gaseous pollutants. Toxicol In Vitro 2012; 27: 632-40.

9. Heinrich J. Influence of indoor factors in dwellings on the development of childhood asthma. Int J Hyg Environm Health 2011; 214: 1-25.

10. Jantunen M, Oliveira FE, Carrer, et al. Promoting actions for healthy indoor air (IAIAQ) (2011). European Commission Directorate General for Health and Consumers. Luxembourg.

11. Gilbert NL, Guay M, Gauvin D, et al. Air change rate and concentration of formaldehyde in residential indoor air. Atmospher Environm 2008; 42: 2424-8.

12. Bönisch U, Böhme A, Kohajda T, et al. Volatile organic compounds enhance allergic airway inflammation in an experimental mouse model. PLoS One 2012; 7: e39817

13. Siemiński M. Środowiskowe zagrożenia zdrowia. Wydawnictwo PWN, Warszawa 2007.

14. Richardson G, Eick S, Jones R. How is the indoor environment related to asthma? Literature review. J Adv Nursing 2005; 52: 328-39.

15. Diette GB, McCormack MC, Hansel NN, et al. Environmental issues in managing asthma. Respir Care 2008; 53: 602-17.

16. Trupin L, Balmes JR, Chen H, et al. An integrated model of environmental factors in adult asthma lung function and disease severity: a cross-sectional study. Environ Health 2010; 9: 24.

17. Samoliński B. Allergy to house dust mites - diagnosis and therapy. Alergia 2016; 3: 39-42.

18. Belanger K, Triche EW. Indoor combustion and asthma. Immunol Allergy Clin North Am 2008; 28: 507-19.

19. Thorn J, Brisman J, Torén K. Adult-onset asthma is associated with self-reported mold or environmental tobacco smoke exposures in the home. J Allergy Clin Immunol 2001; 56: 287-92. 